\title{
Pengaruh Biochar Sekam Padi dan Kompos Paitan (Tithonia diversifolia) terhadap Pertumbuhan Tanaman Kacang Hijau(Vigna radiata L.) di Tanah Miditeran
}

\section{(Effect of Rice Husk Biochar and the Thitonia Compost on Growth and Yield of Mungbean grown on Mediteranian soil)}

\author{
Muhammad Amin Sadzli ${ }^{1}$ dan Ir. Slamet Supriyadi ${ }^{1 *}$ \\ Program Studi Agroteknologi Fakultas Pertanian Universitas Trunojoyo Madura \\ Jalan Raya Telang PO BOX 02 Kamal, Bangkalan, Madura \\ *Email korespondensi: slamspy9@gmail.com, aminnggambleh1@gmail.com
}

Diterima 28 Agustus 2019/Disetujui 04 Oktober 2019

\begin{abstract}
Biochar is a black material resulted from pyrolysis of carbonaceous raw materials at certain temperature and commonly used as a soil conditioner. Its application may improve soil properties including organic C content. Compost addition may increase biochar performance in amending soil properties. This study aimed to examine the interaction between rice hull biochar and compost of Tithonia diversifolia on the growth of green beans (Vigna radiata L.). The research was conducted at the Experimental Station Agrotechnology, Faculty of Agriculture, University of Trunojoyo Madura located at $5 \mathrm{~m}$ above sea from May to August 2018. The research was arranged on a completely randomized design (CRD) with two factors. First factor was addition of Tithonia compost consisting of $O(P 0)$ and $5(P 1)$ tons/ha. Second factor was biochar application consisting of 0 (BO), 5 (B1), and 10 (B2) tons/ha. Results showed that significant interaction effect of rice husk biochar and Tithonia compost on the growth of mung bean at 3 WAP, increasing soil C-organic up to $180 \%$, and reduced volume density of soil however (BI), the are reduced the percentage of effective nodules.
\end{abstract}

Keywords: Green Beans (Vigna radiata L.), biochar, Tithonia compost, C-organic.

\section{ABSTRAK}

Biochar adalah padatan berwarna hitam mirip arang hasil pirolisis materi kaya karbon yang mampu memperbaiki sifat-sifat tanah termasuk peningkatkan kandungan C-organik dalam tanah. Penambahan kompos pada biochar kemungkinan akan meningkatkan kinerja biochar sebagai pembenah tanah. Penelitian ini bertujuan mengkaji interaksi antara biochar sekam padi dan kompos Tithonia pada pertumbuhan kacang hijau (Vigna radiata L.). Penelitian dilaksanakan dari bulan Mei hingga Agustus 2018, dalam Rumah plastik di Kebun Percobaan Agroteknologi, Fakultas Pertanian, Universitas Trunojoyo Madura, terletak di ketinggian $\pm 5 \mathrm{~m}$ dpl. Percobaan disusun dalam Rancangan Acak Lengkap (RAL) dengan 2 faktor, yaitu penambahan kompos Thitonia dalam takaran $0(P 0)$ dan 5 (P1) ton/ha; dan faktor kedua adalah penambahan biochar sekam padi sebanyak 0 (B0), 5 (B1), 10 (B2), dan 10 (B3) ton/ha. Hasil penelitian menunjukkan terdapat pengaruh interaksi biochar sekam padi dan kompos Tithonia terhadap pertumbuhan kacang hijau (Vigna radiata L.) pada parameter tinggi tanaman 3 MST, meningkatan kandungan C-organik tanah hingga 180\%, dan menurunkan Bobot Isi (BI) tanah, dan cenderung menurunkan persentase bintil akar efektif. Efek biochar secara umum lebih baik jika konpos diikutkan daripada diberikan terpisah.

Kata kunci: Kacang Hijau (Vigna radiata L.), biochar, kompos Tithonia, C-organik.

\section{PENDAHULUAN}

Tanah merupakan lapisan permukaan bumi yang secara fisik berfungsi sebagai tempat tumbuh dan berkembang perakaran tanaman dan menyediakan kebutuhan air dan udara. Secara kimiawi berfungsi sebagai penyedia hara dan nutrisi. Secara Biologis berfungsi sebagai habitat organisme yang berpartisipasi dalam penyediaan hara sebagai pemicu tumbuh dan proteksi bagi tanaman. (Hanafiah, 2014).

Tanah sangat rentan terhadap degradasi tanah apabila pengelolaannya tidak tepat. Degradasi tanah adalah menurunnya kandungan unsur hara, bahan organik tanah, terganggunya siklus karbon $(\mathrm{C})$, nitrogen $(\mathrm{N})$, fosfor $(\mathrm{P})$, sulfur (S), dan memburuknya struktur dan pemadatan tanah sehingga tanah tersebut menjadi tanah kristis. Perlu adanya pembenah tanah untuk mengembalikan kondisi tanah berupa bahan organik seperti pupuk organik, kompos, dan biochar. Salah satu jenis pupuk organik adalah memanfaatkan gulma invasiv tanaman paitan (Tithonia diversifolia). Bahan lain yang dapat digunakan sebagai pembenah tanah adalah biochar sekam padi. Menurut Steiner et al. (2007) biochar 
sebagai bahan pembenah tanah memiliki sifat lebih tahan terhadap oksidasi dan lebih stabil dalam tanah sehingga memiliki pengaruh jangka panjang terhadap perbaikan kualitas kesuburan tanah (C-organik tanah dan KTK).

Di Indonesia paitan (Tithonia diversifolia) belum banyak dimanfaatkan, padahal merupakan sumber pupuk organik atau bahan organik tanah (Hartatik, 2007). Purwani (2011) melaporkan paitan (Tithonia diversifolia) memiliki kandungan hara 2,7-3,59\% $\mathrm{N} ; 0,14-0,47 \% \mathrm{P}$; dan 0,25$4,10 \%$ K. Hasil penelitian Hutomo et al. (2015) menunjukkan bahwa dengan pemberian pupuk hijau paitan dosis 10 ton per ha dapat meningkatakan hasil tanaman jagung sebesar 9,2 ton/ha. Bagian tanaman paitan yang digunakan sebagai pupuk organik adalah batang dan daunnya. Pemanfaatan paitan sebagai sumber hara, yaitu dapat dimanfaatkan dalam bentuk pupuk organik segar, pupuk organik cair, atau kompos (Hakim et al., 2012). Namun, keuntungan pembenah seperti ini bersifat jangka pendek, terutama di daerah tropis seperti Indonesia. Hal ini disebabkan oleh cepatnya proses dekomposisi bahan organik tersebut. Oleh sebab itu, penambahan bahan organik dari bahan yang mengandung karbon yang relatif tahan pelapukan ke tanah perlu dilakukan untuk mempertahankan kesuburan tanah.

Maka diperlukan sebuah penelitian untuk mengetahui pengaruh biochar arang sekam yang dikombinasikan dengan pupuk organik paitan (Tithonia diversifolia) pada pertumbuhan tanaman kacang hujau (Vigna radiata L.).

\section{METODE PENELITIAN}

Penelitian ini dilaksanakan di Kebun Percobaan Agroteknologi, Fakultas Pertanian, Universitas Trunojoyo Madura yang berada pada ketinggian $\pm 5 \mathrm{~m}$ dpl. Penelitian ini dilaksanakan dari bulan Mei hingga Agustus 2018.

Alat yang digunakan dalam penelitian ini adalah ayakan dengan ukuran $2 \mathrm{~mm}$, seng, cangkul, sekop, pisau, kertas label, papan nama, ember atau gembor, gelas ukur, alat tulis, penggaris, meteran, kamera, sabit, palu, dan alatalat lainnya yang mendukung penelitian ini. Bahan yang digunakan dalam penelitian ini yaitu tanah mediteran, air, EM-4, gula merah, bekatul, sekam padi, pot, tanaman Paitan (Tithonia diversifolia), dan benih Kacang Hijau (Vigna radiata L.) varietas Vima-1.

\section{Rancangan Percobaan}

Rancangan percobaan pada penelitian ini menggunakan Rancangan Acak Lengkap (RAL) dengan 2 faktor, yaitu :

Faktor pertama dosis pupuk organik tanaman paitan (Tithonia diversifolia) terdiri dua taraf perlakuan, yaitu :

$$
\mathrm{P} 0: 0 \text { ton } / \mathrm{ha}=0 \mathrm{~g} / \text { pot. }
$$$$
\mathrm{P} 1: 5 \text { ton } / \mathrm{ha}=13,46 \mathrm{~g} / \text { pot. }
$$

Faktor kedua dosis biochar sekam padi terdiri tiga taraf perlakuan, yaitu :

$$
\begin{aligned}
& \text { B } 0: 0 \text { ton } / \mathrm{ha}=0 \mathrm{~g} / \text { pot. } \\
& \text { B1 }: 5 \text { ton } / \mathrm{ha}=13,46 \mathrm{~g} / \text { pot. } \\
& \text { B2 }: 10 \text { ton } / \mathrm{ha}=26,92 \mathrm{~g} / \mathrm{pot} .
\end{aligned}
$$

\section{Persiapan Media Tanam}

a) Tanah

Media tanam yang digunakan adalah tanah mediteran yang sudah dikeringanginkan dan lolos ayakan 2,0 mm sebanyak $7 \mathrm{~kg}$ dan dimasukkan dalam pot berukuran $30 \times 25$ $\mathrm{cm}$.

b) Biochar

Biochar yang digunakan adalah biochar yang terbuat dari arang sekam padi. Sekam padi disangrai diatas seng yang bawahnya berlubang. Agar terbakar tidak sempurnna biochar yang sudah disangrai lalu disiram dengan air agar tidak menjadi abu, kemudian biochar dikering anginkan (selama 2 hari) hingga tidak ada air yang tersisa.

c) Pupuk Organik Paitan ((Tithonia diversifolia)

Pupuk yang digunakan adalah pupuk organik yang berasal dari tumbuhan paitan dengan cara dikomposkan. Bagian tanaman yang digunakan adalah daun dan batang.

\section{Persiapan Bahan Tanam dan Penanaman}

Tanaman indikator yang digunakan adalah tanaman kacang hijau. Sebelum melakukan penanaman ada beberapa hal yang perlu dilakukan, antara lain :

a) Penyiapan benih, pemilihan benih dilakukan dengan cara perendaman benih, dimana yang terapung dibuang, dan benih terbenam yang digunakan.

b) Penyiapan media tanam, dalam media tanam telah dicampur antara tanah, biochar, pupuk organik paitan sesuai dengan perlakuan masing-masing. Pencampuran dilakukan per pot untuk memastikan bahwa setiap pot mendapat campuran biochar dan kompos sesuai perlakuan.

c) Penanaman benih, penanaman dilakukan 2 hari setelah penyiapan media tanam. Penanaman dilakukan dengan menanam 3 benih per lubang tanam pada kedalaman $2 \mathrm{~cm}$ dari permukaan tanah kemudian lubang tanam ditutup kembali.

\section{Penjarangan}

Penjarangan tanaman dilakukan setelah tanaman berumur 1 MST. Penjarangan dilakukan dengan memotong 2 tanaman dengan gunting sehingga hanya tinggal 1 tanaman yang baik pertumbuhannya.

\section{Pemeliharaan}

Pemeliharaan tanaman yang dilakukan pada penelitian ini antara lain penyiraman, penyiangan, dan pengendalian hama dan penyakit.

\section{Pemanenan}

Sebelum tahap pemanenan, sampel tanah diambil terlebih dahulu pada setiap perlakuan untuk analisis media tanam. Pemanenan dilakukan pada umur 8 MST dengan mencabut seluruh bagian tanaman dari akar sampai daun 
dengan hati-hati supaya tidak menyebabkan kerusakan pada hasil tanaman.

\section{Analisa Media Tanam}

Analisa media tanam dilakukan setelah tahap pemanenan kacang hijau selesai, yaitu dengan mengambil sampel dari media tanam tanaman kacang hijau yang sudah dipanen. Kemudian sampel tanah yang sudah diambil akan dianalisis untuk mengetahui besar kandungan C-organik, dan pH. Analisa tanah dilakukan di Laboratorium Dasar Universitas Trunojoyo Madura. Analisa ini dilakukan untuk mengetahui besar peningkatan kandungan tanah sebelum dan setelah perlakua

\section{Parameter Pengamatan}

Parameter pengamatan yang dilakukan pada penelitian ini antara lain :

a) Tinggi Tanaman $(\mathrm{cm})$

Tinggi tanaman diukur mulai dari pangkal batang yang ada di permukaan tanah hingga titik tumbuh tanaman. Pengamatan ini dilakukan mulai 1 MST setiap 7 hari sekali.

b) Jumlah Cabang (cabang)

Jumlah cabang ini dilakukan dengan menghitung seluruh jumlah cabang yang terdapat pada setiap tanaman. Pengamatan ini dilakukan mulai 1 MST setiap 7 hari sekali.

c) Bobot Basah Brangkasan (g)

Berat basah ini dipisahkan antara tajuk dan akarnya, berat basah dihitung dengan cara menimbang bobot bagian tajuk dan akar saat setelah panen.

d) Bobot Kering Brangkasan (g)

Berat kering ini dihitung setelah di oven, basah kering dihitung dengan cara menimbang bobot bagian tajuk dan akar saat setelah di oven.

e) Bobot dan Jumlah Bintil Akar (g)
Menghitung jumlah bintil akar keseluruhan pada tiap tanaman lalu menimbangnya. Kemudian bintil akar dari tiap tanaman diamati untuk menentukan bintil akar efektifnya dengan cara dibelah menjadi 2 bagian apakah bintil akar tersebut berwarna merah atau tidak, jika berwarna merah itu termasuk bintil akar efektif. Setelah itu menghitung jumlah dan berat dari bintil akar efektif dari tiap tanaman.

f) Analisa Media Tanam

Analisa ini dilakukan untuk mengetahui besar peningkatan kandungan C-organik, dan $\mathrm{pH}$ sebelum dan setelah perlakuan.

\section{Analisis Data}

Data dianalisis menggunakan Analisis Sidik Ragam dan apabila berpengaruh nyata dilanjutkan Uji Beda Jarak Nyata Duncan (BJND) taraf 5\%.

\section{HASIL DAN PEMBAHASAN}

\section{Tinggi Tanaman}

Hasil dari analisis analisis sidik ragam pengaruh pemberian biochar dan kompos memberikan pengaruh nyata terhadap parameter tinggi tanaman. Rerata tinggi tanaman akibat pengaruh perlakuan dapat dilihat pada Tabel 1 .

Berdasarkan Tabel 1 menunjukkan bahwa perlakuan pemberian kompos memberikan pengaruh nyata pada 3 MST dengan rerata tertinggi pada perlakuan P1 yang berbeda nyata dengan perlakuan P0. Selain itu, pada 7 MST dan 8 MST perlakuan pemberian biochar memberikan pengaruh nyata dengan rerata cenderung tinggi pada perlakuan yang sama yaitu perlakuan B2 yang berbeda nyata dengan perlakuan $\mathrm{B} 0$.

Terdapat interaksi antara perlakuan biochar dan kompos pada umur 3 MST. Pengaruh interaksi pemberian biochar dan kompos terhadap parameter tinggi tanaman kacang hijau dapat dilihat pada Tabel 2.

Tabel 1. Rerata Tinggi Tanaman (cm) Akibat Perlakuan Pemberian Biochar Sekam Padi dan Kompos Paitan.

\begin{tabular}{|c|c|c|c|c|c|c|c|c|}
\hline \multirow{2}{*}{ Perlakuan } & \multicolumn{8}{|c|}{ Tinggi Tanaman Pada (MST) } \\
\hline & 1 & 2 & 3 & 4 & 5 & 6 & 7 & 8 \\
\hline $\mathrm{P} 0$ & 22,80 & 22,55 & $29,66 \mathrm{a}$ & 32,10 & 39,66 & 47,83 & 62,75 & 65,63 \\
\hline $\mathrm{P} 1$ & 24,25 & 27,83 & $33,53 \mathrm{~b}$ & 35,21 & 45,66 & 56,50 & 70,08 & 72,66 \\
\hline BNJD 5\% & ns & ns & $*$ & $\mathrm{~ns}$ & ns & ns & $\mathrm{ns}$ & ns \\
\hline B0 & 25,22 & 27,77 & 32,40 & 33,78 & 39,20 & 45,13 & $52,25 \mathrm{a}$ & $54,38 \mathrm{a}$ \\
\hline B1 & 22,50 & 26,70 & 31,18 & 34,20 & 43,50 & 54,63 & $72,88 \mathrm{~b}$ & $76,08 \mathrm{~b}$ \\
\hline $\mathrm{B} 2$ & 22,85 & 25,60 & 31,23 & 33,00 & 45,30 & 113,50 & $74,13 \mathrm{~b}$ & $77,00 \mathrm{~b}$ \\
\hline BNJD 5\% & $\mathrm{ns}$ & $\mathrm{ns}$ & ns & $\mathrm{ns}$ & $\mathrm{ns}$ & ns & $*$ & $*$ \\
\hline
\end{tabular}

Keterangan: angka-angka yang diikuti huruf yang sama dalam kolom yang sama menunjukkan tidak berbeda nyata pada uji BJND pada taraf $5 \%$. 
Tabel 2. Rerata Tinggi Tanaman (cm) Akibat Interaksi Perlakuan Pemberian Biochar Sekam Padi dan Kompos Paitan Pada Umur 3 MST.

\begin{tabular}{cc}
\hline Perlakuan & Tinggi Tanaman Pada 3 MST \\
\hline P0B0 & $7,38 \mathrm{ab}$ \\
P0B1 & $8,24 \mathrm{ab}$ \\
P0B2 & $6,64 \mathrm{a}$ \\
P1B0 & $8,83 \mathrm{~b}$ \\
P1B1 & $7,35 \mathrm{ab}$ \\
P1B2 & $8,98 \mathrm{~b}$ \\
\hline
\end{tabular}

Bjnd $5 \%$

Keterangan: angka-angka yang diikuti huruf yang sama dalam kolom yang sama menunjukkan tidak berbeda nyata pada uji BJND pada taraf $5 \%$.

Tabel 3. Rerata Jumlah Cabang Akibat Perlakuan Pemberian Biochar Sekam Padi dan Kompos Paitan.

\begin{tabular}{|c|c|c|c|c|c|c|}
\hline \multirow{2}{*}{ Perlakuan } & \multicolumn{6}{|c|}{ Jumlah Cabang Pada (MST) } \\
\hline & 3 & 4 & 5 & 6 & 7 & 8 \\
\hline P0 & 7,33 & 9,00 & 15,33 & 23 & 31,16 & 31,66 \\
\hline $\mathrm{P} 1$ & 8,16 & 10,16 & 17,33 & 27,83 & 33,50 & 35,66 \\
\hline BJND 5\% & ns & ns & Ns & Ns & ns & ns \\
\hline B0 & 7,00 & 9,50 & 15,25 & 20,75 & $26,25 \mathrm{a}$ & $27,25 \mathrm{a}$ \\
\hline B1 & 8,25 & 9,75 & 16,75 & 27,00 & $35,50 \mathrm{~b}$ & $36,25 \mathrm{~b}$ \\
\hline $\mathrm{B} 2$ & 8,00 & 9,50 & 17,00 & 28,50 & $35,25 \mathrm{~b}$ & $37,50 \mathrm{~b}$ \\
\hline BJND 5\% & ns & ns & Ns & Ns & * & * \\
\hline
\end{tabular}

Keterangan: angka-angka yang diikuti huruf yang sama dalam kolom yang sama menunjukkan tidak berbeda nyata pada uji BJND pada taraf $5 \%$.

Tabel 4. Rerata Bobot Basah (BB) Brangkasan Akibat Perlakuan Pemberian Biochar Sekam Padi dan Kompos Paitan.

\begin{tabular}{ccc}
\hline \multirow{2}{*}{ Perlakuan } & \multicolumn{2}{c}{ Bobot Basah Brangkasan } \\
\cline { 2 - 3 } & Bobot Akar $(\mathrm{g})$ & Bobot Tajuk $(\mathrm{g})$ \\
\hline P0 & 10,04 & 46,75 \\
P1 & 12,11 & 62,51 \\
\hline BJND 5\% & Ns & Ns \\
\hline B0 & $9,07 \mathrm{a}$ & $64,13 \mathrm{~b}$ \\
B1 & $12,36 \mathrm{~b}$ & $63,67 \mathrm{~b}$ \\
\hline
\end{tabular}

BJND 5\%

Keterangan : angka-angka yang diikuti huruf yang sama dalam kolom yang sama menunjukkan tidak berbeda nyata pada uji BJND pada taraf $5 \%$.

Berdasarkan Tabel 2 dapat dilihat bahwa rerata tinggi tanaman cenderung tinggi yaitu pada perlakuan P1B2 dan terendah yaitu pada perlakuan P0B2.

\section{Jumlah Cabang}

Hasil dari analisis analisis sidik ragam pengaruh pemberian biochar memberikan pengaruh nyata terhadap parameter jumlah cabang (Lampiran 2). Rerata jumlah cabang akibat pengaruh perlakuan dapat dilihat pada Tabel 3.

Berdasarkan Tabel 3 menunjukkan bahwa perlakuan pemberian biochar memberikan pengaruh nyata pada 7 dan 8 MST. Pada 7 MST dengan rerata cenderung tinggi pada 
perlakuan B1 yang berbeda nyata dengan perlakuan B0. Sedangkan pada 8 MST dengan rerata tertinggi pada perlakuan B2 yang yang berbeda nyata dengan B0.

Hal ini diduga karena biochar sebagai pembenah tanah mampu memberikan ketersediaan unsur hara bagi tanaman yang cukup stabil. Tersedianya nutrisi yang cukup pada fase pertumbuhan ini dapat memacu proses pembelahan dan diferensiasi sel untuk membentuk tunas baru, sehingga jumlah cabang dan daun yang terbentuk semakin banyak (Ariyanti et al. 2017).

\section{Bobot Basah (BB) Brangkasan}

Hasil dari analisis analisis sidik ragam pengaruh pemberian biochar memberikan pengaruh nyata terhadap parameter bobot basah brangkasan tanaman kacang hijau meliputi bobot akar (g) dan tajuk (g) (Lampiran 3 dan 4). Rerata bobot akar (g) dan tajuk (g) akibat pengaruh perlakuan dapat dilihat pada Tabel 4 .

Berdasarkan Tabel 4 menunjukkan bahwa perlakuan pemberian biochar memberikan pengaruh nyata pada bobot akar dan bobot tajuk dengan rerata cenderung tinggi pada perlakuan yang sama yaitu perlakuan B1 yang berbeda nyata dengan perlakuan B0.

\section{Bobot Kering (BK) Brangkasan}

Hasil dari analisis analisis sidik ragam pengaruh pemberian biochar memberikan pengaruh nyata terhadap parameter bobot kering brangkasan tanaman kacang hijau meliputi bobot akar (g) dan tajuk (g) (Lampiran 7). Rerata bobot akar (g) dan bobot tajuk (g) akibat pengaruh perlakuan dapat dilihat pada Tabel 5.

Berdasarkan Tabel 5 menunjukkan bahwa perlakuan pemberian biochar memberikan pengaruh nyata pada bobot tajuk dengan rerata cenderung tinggi pada perlakuan B1 yang berbeda nyata dengan perlakuan B0.

Hal ini menunjukkan bahwa tanah yang sudah diberi bahan organik memilki kandungan hara yang lebih dari pada yang tanpa perlakuan, hal itu dapat dilihat pada rerata jumlah bintil akar keseluruhan dan efektif yang lebih rendah dari pada yang tanpa perlakuan. Bintil akar yang ada pada akar dapat dijadikan indikator kesuburan dalam tanah.

\section{Bintil Akar}

Hasil dari analisis analisis sidik ragam pengaruh pemberian biochar dan kompos memberikan pengaruh yang nyata terhadap parameter bintil akar keseluruhan maupun bintil akar efektif tanaman kacang hijau yang meliputi jumlah bintil (biji) dan berat bintil (g) (Lampiran 5 dan 6). Rerata parameter bintil akar tanaman kacang hijau dapat dilihat pada Tabel 6 .

Berdasarkan Tabel 6 menunjukkan bahwa perlakuan pemberian kompos memberikan pengaruh nyata pada jumlah bintil keseluruhan dengan rerata tertinggi pada perlakuan P1 dan pada bobot bintil efektif dengan rerata tertinggi pada perlakuan P0. Sedangkan pada perlakuan pemberian biochar memberikan pengaruh nyata pada pada jumlah bintil dan bobot bintil keseluruhan dengan rerata tertinggi pada perlakuan yang sama yaitu perlakuan B1.

Rosmarkam (2002) menyatakan bahwa penambatan $\mathrm{N}$ oleh rhizobia akan maksimum bila ketersediaan hara nitrogen dalam keadaan minimum. Terdapat interaksi antara perlakuan biochar dan kompos paitan (Tabel 6) yang memberikan pengaruh nyata pada bintil akar efektif meliputi jumlah bintil maupun berat bintil.

Interaksi antara perlakuan biochar dan kompos dapat dilihat pada Tabel 7. Berdasarkan Tabel 7 dapat dilihat bahwa pada bintil akar keseluruhan meliputi jumlah bintil dan berat bintil memiliki hasil yang tidak berpengaruh nyata. Sedangkan pada bintil akar efektif meliputi jumlah bintil maupun berat bintil memberikan pengaruh nyata. Pada jumlah bintil efektif memiliki rerata cenderung tinggi pada perlakuan P1B1 dan terendah pada P1B0. Sedangkan pada bobot basah bintil efektif memiliki rerata cenderung tinggi pada perlakuan P0B0 dan terendah pada perlakuan P1B0.

Hal tersebut diduga bahwa kandungan $\mathrm{N}$ yang ada dalam tanah akibat pemberian kompos dapat memberikan pengaruh pada aktivitas rhizobia menjadi kurang efektif karena sudah tersedianya hara nitrogen pada tanah.

Tabel 5. Rerata Bobot Kering (BK) Brangkasan Pada Perlakuan Pemberian Biochar Sekam Padi dan Kompos Paitan.

\begin{tabular}{ccc}
\hline \multirow{2}{*}{ Perlakuan } & \multicolumn{3}{c}{ Bobot Kering (Brangkasan) } \\
\cline { 2 - 3 } & Akar $(\mathrm{g})$ & Tajuk $(\mathrm{g})$ \\
\hline P0 & 1,16 & 6,83 \\
P1 & 1,55 & 8,95 \\
\hline BJND 5\% & $\mathrm{ns}$ & $\mathrm{ns}$ \\
\hline B0 & 1,06 & $5,7 \mathrm{a}$ \\
B1 & 1,60 & $9,45 \mathrm{~b}$ \\
B2 & 1,40 & $8,52 \mathrm{~b}$ \\
\hline BJND 5\% & $\mathrm{ns}$ & $*$
\end{tabular}

Keterangan: angka-angka yang diikuti huruf yang sama dalam kolom yang sama menunjukkan tidak berbeda nyata pada uji BJND pada taraf $5 \%$. 
Tabel 6. Rerata Bintil Akar Akibat Perlakuan Pemberian Biochar Sekam Padi dan Kompos Paitan.

\begin{tabular}{|c|c|c|c|c|}
\hline \multirow{3}{*}{ Perlakuan } & \multicolumn{4}{|c|}{ Bintil Akar } \\
\hline & \multicolumn{2}{|c|}{ Keseluruhan } & \multicolumn{2}{|c|}{ Efektif } \\
\hline & $\Sigma$ Bintil (biji) & Bobot Basah Bintil (g) & $\Sigma$ Bintil (biji) & Bobot Basah Bintil (g) \\
\hline P0 & $63 \mathrm{a}$ & 0,4978 & 11 & $0,1057 \mathrm{~b}$ \\
\hline $\mathrm{P} 1$ & $98 \mathrm{~b}$ & 0,4430 & 9 & $0,0674 \mathrm{a}$ \\
\hline BJND 5\% & $*$ & Ns & ns & $*$ \\
\hline B0 & $64 \mathrm{a}$ & $0,3309 \mathrm{a}$ & 4 & 0,0362 \\
\hline B1 & $96 \mathrm{c}$ & $0,5428 \mathrm{~b}$ & 5 & 0,0361 \\
\hline B2 & $81 \mathrm{~b}$ & $0,5375 \mathrm{~b}$ & 4 & 0,0431 \\
\hline BJND 5\% & $*$ & $*$ & ns & ns \\
\hline
\end{tabular}

Keterangan: angka-angka yang diikuti huruf yang sama dalam kolom yang sama menunjukkan tidak berbeda nyata pada uji BJND pada taraf $5 \%$.

Tabel 7. Rerata Bintil Akar Akibat Interaksi Perlakuan Pemberian Biochar Sekam Padi dan Kompos Paitan.

\begin{tabular}{ccc}
\hline \multirow{2}{*}{ Perlakuan } & \multicolumn{2}{c}{ Bintil Akar Efektif } \\
\cline { 2 - 3 } & $\sum$ Bintil (biji) & Bobot Basah Bintil (g) \\
\hline P0B0 & $8 \mathrm{bc}$ & $0,0869 \mathrm{~d}$ \\
P0B1 & $6 \mathrm{abc}, 0467 \mathrm{ab}$ \\
P0B2 & $8 \mathrm{bc}$ & $0,0779 \mathrm{bcd}$ \\
P1B0 & $3 \mathrm{a}$ & $0,0216 \mathrm{a}$ \\
P1B1 & $9 \mathrm{c}$ & $0,0617 \mathrm{bc}$ \\
P1B2 & $5 \mathrm{ab}$ & $0,0516 \mathrm{abc}$ \\
\hline BJND 5\% & $*$ & $*$
\end{tabular}

Keterangan: angka-angka yang diikuti huruf yang sama dalam kolom yang sama menunjukkan tidak berbeda nyata pada uji BJND pada taraf $5 \%$.

Tabel 8. Kandungan C-organik, pH, dan BI Tanah Akibat Perlakuan Biochar Sekam Padi dan Kompos Paitan.

\begin{tabular}{cccr}
\hline & \multicolumn{3}{c}{ Parameter } \\
\cline { 2 - 4 } Perlakuan & C-organik $(\%)$ & $\mathrm{pH}$ & BI Tanah \\
\hline P0B0 & 0,84 & 7,0 & 1,10 \\
P0B1 & 1,53 & 7,1 & 1,04 \\
P0B2 & 1,97 & 7,2 & 0,94 \\
P1B0 & 1,81 & 7,1 & 0,98 \\
P1B1 & 2,15 & 7,2 & 1,06 \\
P1B2 & 2,36 & 7,2 & 0,96 \\
\hline
\end{tabular}

Penambahan biochar ke tanah keungkinan juga dapat meningkatkan total $\mathrm{N}$ dan kapasitas tukar kation tanah (KTK). Pada saat fase pertumbuhan tanaman akan menyerap unsur hara $\mathrm{N}$ dalam tanah untuk pembentukan akar dan kondisi tanah yang subur akan mendukung untuk pembentukan dan pertumbuhan akar.

Biochar juga memliki sifat lebih efektif dalam retensi unsur hara dalam tanah dibanding bahan organik lain seperti kompos dan pupuk kandang, sehingga tanaman masih bisa menyerap unsur hara untuk memenuhi kebutuhannya. Ini sependapat dengan Steiner et al. (2007) biochar sebagai bahan pembenah tanah memiliki sifat rekalsitran, lebih tahan terhadap oksidasi dan lebih stabil dalam tanah sehingga memiliki pengaruh jangka panjang terhadap perbaikan kualitas kesuburan tanah (C-organik tanah dan KTK).

\section{Kandungan C, pH, dan BI Tanah Dalam Media}

Analisa nilai kandungan $\mathrm{C}$-organik dan $\mathrm{pH}$ sesudah 
panen dilakukan dengan mengkompositkan sampel media tanam, dapat dilihat pada Tabel 8.

Berdasarkan Tabel 8 dapat dilihat bahwa C-organik cenderung meningkat dengan meningkatnya biochar, dengan kandungan cenderung tinggi pada P1B2. Kombinasi P1B1 dan P1B2 meningkatkan C-organik dalam tanah hingga $180 \%$, sehingga klas kandungan $\mathrm{C}$ dalam taneh yang semula sangat rendah $(<1 \%)$ menjadi sedang (> 2\%). Aplikasi biochar cenderung menaikkan $\mathrm{pH}$ tanah sekitar 0,2 unit $\mathrm{pH}$ dan menurunkan BI Tanah.

Hal tersebut menunjukkan bahwa dengan penambahan bahan organik pada tanah selain dapat meningkatkan kandungan $\mathrm{C}$ pada tanah juga dapat mengurangi berat isi tanah. Ini sesuai dengan fungsi dari biochar sebagai bahan organik pembenah tanah yang akan memperbaiki kondisi tanah yang akan menjadi lebih remah. Tanah yang memiliki BI kecil akan mampu memudahkan akar-akar tanaman untuk menembus tanah untuk memperoleh unsur hara tanah sehingga sistem perakaran tanaman menjadi baik dan tanaman tumbuh dengan baik. Dwi et al. (2018) menyatakan bahwa pemberian bahan organik kedalam tanah dapat meningkatkan jumlah ruang pori tanah dan membentuk struktur tanah yang remah sehingga akan menurunkan berat isi tanah.

\section{KESIMPULAN}

\section{Kesimpulan}

Berdasarkan hasil penelitian dapat disimpulkan bahwa terdapat pengaruh interaksi perlakuan biochar sekam padi dan kompos Tithonia terhadap pertumbuhan kacang hijau (Vigna radiata L.) pada variabel tinggi tanaman 3 MST, dan persentase bintil akar efektif. Hasil terbaik tinggi tanaman diperoleh dari perlakuan P1B0 dan P1B2, dan persentase bintil akar mengalami penurunan tertinggi pada perlakuan P1B0. Aplikasi biochar meningkatkan kandungan $\mathrm{C}$ organik dalam tanahhingga $180 \%$ dan $\mathrm{pH}$ tanah hingga 0,2 unit $\mathrm{pH}$ serta menurunkan bobot isi tanah.

\section{Saran}

Perlu dilakukan penelitian tentang pengaruh kompos Tithonia pada takaran yang lebih tinggi dengan kombinasi biochar terhadap pertumbuhan dan produksi tanaman kacang hijau (Vigna radiata L.). Efek biochar biasanya berlangsung dalam waktu yang lama, maka perlu pengamatan efek residu perlakuan di musim tanam berikutnya.

\section{DAFTAR PUSTAKA}

Aryanti, D. Adiwirman dan G. Tabrani. 2017. Respon Kacang Hijau (Phaseolus radiatus L.) Terhadap Ekstrak Rebung Bambu Betung (Dendrocalamus asper Backer.) Dengan Pupuk Hijau Tithonia (Tithonia diversifolia). Jom Faperta. 4(1):1-13.

Dwi, S., D.P. Rakhim dan A. Kusuma, Z. 2018. Hubungan Kandungan Bahan Organik Tanah Dengan Berat Isi, Porositas Dan Laju Infiltrasi Pada Perkebunan Salak Di Kecamatan Purwosari, Kabupaten Pasuruan. Jurnal Tanah Dan Sumberdaya Lahan 5 (1) : 647654.

Hakim, N., Agustian dan Y. Mala. 2012. Application of organic fertilizer Tithonia plus to control iron toxicity and reduce commercial fertilizer application on new paddy field. J. Trop. Soils 17(2):135-142.

Hanafiah, K.A. 2012. Dasar-DasarIlmu Tanah. Rajawali Pers: Jakarta. Hal: 4.

Hartatik, W. 2007. Tithonia diversifolia Sumber Pupuk Hijau. Warta Penelitian Dan Pengembangan Pertanian 29(5):3-5.

Hutomo, I. 2015. Pengaruh Pupuk Hijau Tithonia diversifolia Terhadap Pertumbuhan dan Hasil Tanaman Jagung (Zea mays L.). Agrotekbis 3(4): 475-481

Purwani, J. 2011. Pemanfaatan Tithonia diversifolia untuk Perbaikan Tanah. Balai Penelitian Tanah, 253-263.

Rosmarkam, A. dan Nasih, W., Y. 2002. Ilmu Kesuburan Tanah. Kanisius: Yogyakarta. Hal: 29-95.

Steiner, C. 2007. Soil Charcoal Amendments Maintain Soil Fertility and Establish Carbon Sink and Prospects. Soil Ecology Res Dev, 1-6. 